\title{
Review \\ Arthrospira platensis as a Feasible Feedstock for Bioethanol Production
}

\author{
Enrique Gonzalez Bautista and Céline Laroche *
}

Citation: Gonzalez Bautista, E.; Laroche, C. Arthrospira platensis as a Feasible Feedstock for Bioethanol Production. Appl. Sci. 2021, 11, 6756. https://doi.org/10.3390/app11156756

Academic Editor: Francesca Scargiali

Received: 30 June 2021

Accepted: 22 July 2021

Published: 22 July 2021

Publisher's Note: MDPI stays neutral with regard to jurisdictional claims in published maps and institutional affiliations.

Copyright: (c) 2021 by the authors. Licensee MDPI, Basel, Switzerland. This article is an open access article distributed under the terms and conditions of the Creative Commons Attribution (CC BY) license (https:// creativecommons.org/licenses/by/ $4.0 /)$.
Institute Pascal, UMR CNRS 6602, University Clermont Auvergne, F-63000 Clermont-Ferrand, France; enrique0306@gmail.com

* Correspondence: celine.laroche@uca.fr; Tel.: +33-473-407-419

Keywords: cyanobacteria; Arthrospira; glycogen

\section{Introduction}

Faced with the decrease in available fossil fuel resources, their substitution with biofuels like bioethanol or biodiesel could be a sustainable alternative [1]. Biofuel production can be classified into different generations (from 1st, 2nd, 3rd, until the 4th G) based on the biomass feedstock and processing technology [2]. Each of them has different advantages and drawbacks. Meanwhile, 1st G biofuels use consolidated profitable processes, it competes for arable land with crop production [2]. In this context, 2nd G biofuels use lignocellulosic by-products that do not compete for arable lands, nevertheless, most of the processes are not sustainable at an industrial scale [3]. On the other hand, 3rd and 4th $\mathrm{G}$ are based on low-input autotrophic microbial feedstock, especially microalgae and cyanobacteria (i.e., Chlorella, Arthrospira, Dunaliella, Botryococcus, or Haematococcus) [4,5]. Innovative development of these processes can allow for the production of sustainable amounts of biofuel without competing for arable lands while fixing $\mathrm{CO}_{2}$ via photosynthesis [6]. Indeed, the production of this type of biofuel is expected to be carbon negative both at the level of the raw material (fix atmospheric $\mathrm{CO}_{2}$ ) and process technology (low $\mathrm{CO}_{2}$ emission), helping reducing $\mathrm{CO}_{2}$ emissions and boost climate change mitigation [7].

Arthrospira platensis, also known as 'spirulina', is a filamentous photosynthetic cyanobacterium composed of individual cells (about $8 \mu \mathrm{m}$ in diameter), associated in trichomes (about $500 \mu \mathrm{m}$ length), which grows in subtropical alkaline lakes (pH 8.5 to 10) with an optimum temperature above $35^{\circ} \mathrm{C}$ [8-10]. This cyanobacterium has been studied worldwide for its application in pharmaceutical and health [11], cosmetics [12], nutrition [13], bioremediation [14], and even in oxygen production for closed life support systems in space [15]. Arthrospira platensis is commercialized in at least 22 countries and represents about $60 \%$ of the global microalgal biomass production [5]. The main purpose of the industrial harvest of Arthrospira platensis is the extraction of proteins and bioactive molecules like 
phycocyanin among other compounds [16]. It is also consumed worldwide as a dietary supplement and considered as safe. However, attention has to be paid to the chelating properties of Spirulina species, which can lead to the fixation of heavy metals such as $\mathrm{Al}$, $\mathrm{Pb}, \mathrm{Ba}, \mathrm{Ni}, \mathrm{Cd}$ [17] or fluoride [18]. Nevertheless, this microorganism is also suitable for biofuel production (3rd generation) due to its fast growth, all year cultivation, and chemical composition ( $44.4 \%$ carbohydrates, $45 \%$ proteins, and $10 \%$ lipids and ashes) [19-21]. Its high carbon sequestration rate can reach $0.92 \mathrm{~g} / \mathrm{L} / \mathrm{d}$, making it a feasible biofuel feedstock $[22,23]$. In this context, the main biofuels produced by this cyanobacterium have been solid biofuel [24], bio-oil [25], and syngas [23]. Nevertheless, in recent years, a new approach has been developed, which is the use of Arthrospira platensis storage polysaccharide (i.e., glycogen) for bioethanol production $[26,27]$.

Glycogen ( $\alpha-1,4$ linked glucan) is a polymeric carbohydrate formed of glucose linked through $\alpha-1,4$ and $\alpha-1,6$ glycosidic bonds. This polysaccharide can be degraded via enzymatic hydrolysis (saccharification) and fermented into bioethanol [28]. This energystore polysaccharide is mainly formed in Arthrospira platensis as a response of nutrientstressed conditions, and accumulated (up to $70 \% \mathrm{DW}$ ) in granules in the thylakoid membranes [29-31]. Once conditions are balanced, accumulated glycogen is hydrolyzed to produce energy for cell metabolism. This characteristic of Arthrospira platensis can be exploited to induce glycogen production for bioethanol production [32]. Different modifications in culture medium and culture conditions of Arthrospira platensis can enhance glycogen production. This review aims to aggregate those operating conditions, allowing glycogen accumulation in order to have a better overview of the feasibility of using Arthrospira as a feedstock for bioethanol production.

\section{Growth Requirements for Biomass Production}

The attempt in this first section is just to point out some key parameters influencing biomass production, while the objective of the review is to further highlight specific conditions promoting glycogen accumulation.

Spirulina cultivation has been studied for a long time as it is probably the most cultivated photosynthetic microorganism worldwide. Under this generic name, several cyanobacteria may be encountered, especially species belonging to the genus Arthrospira. In a recent publication from Nowicka-Krawczyk et al. [33], phylogenetic analyses based on the 16S rRNA gene have allowed for a new classification of most of the commercially and bank deposited strains, including creation of a new genus under the name Limnospira to be established. However, this paper will not discriminate between these genus as it is not possible to clearly compare previous works with one or the other.

Since the historical work of Zarrouk [34] on Spirulina maxima, numerous studies have been conducted focusing on abiotic factors such as light intensity, temperature, medium composition, $\mathrm{pH}$, and salinity. Both indoor and outdoor conditions were studied in photobioreactors or open ponds. Subsequently, the individual or the combined effects of these environmental factors on biomass productivity are now well documented.

It is well known that numerous parameters influence the growth or protein content of microalgae: light, temperature, salinity, $\mathrm{CO}_{2}$ addition, nutrient addition, inoculation size, stirring, $\mathrm{pH}$, etc. [34-36]

Most Arthrospira species currently grown in mass culture were isolated from alkaline and saline or brackish waters characterized by high levels of carbonate-bicarbonate and high $\mathrm{pH}$ levels. Zarrouk [34] determined the precise composition of the water in Lake Tchad Lake, a natural habitat for the Arthrospira maxima strain used in his study, allowing him to propose a synthetic medium that is still the basis of all cultivation media classically used for Arthrospira species. However, study of Cogne et al. [37] has shown that all compounds in Zarrouk medium were not necessary to support Arthrospira growth, thus proposing a simplification of the medium. The $\mathrm{pH}$ of these media varies between 8.3 and 10, as Zarrouk [34] showed that the growth rate was similar across this range. Belkin and Boussiba [38] confirmed that the maximal growth rate for Arthrospira was obtained in 
the 9.5-9.8 range. When incubated at $\mathrm{pH} 7.0$, the growth rate of Arthrospira was severely inhibited and was only $20 \%$ of that under the optimal conditions. Moreover, an external $\mathrm{pH}$ of 9.5 will lead to an internal $\mathrm{pH}$ of 7.5, which is the optimal pH for RuBisCo [39]. This high $\mathrm{pH}(>8)$ requirement clearly defines Arthrospira as an obligatory alkaliphile [40].

Generally, the waters populated by Arthrospira have a mean salinity of $37 \mathrm{~g} \mathrm{~L}^{-1}$. However, Arthrospira has been found at salinity levels ranging from 8.5 to $200 \mathrm{~g} \mathrm{~L}^{-1}$ and in at least one case, up to $270 \mathrm{~g} \mathrm{~L}^{-1}$ [41]. Salinity values used for laboratory or mass cultivations generally range from 22 to $60 \mathrm{~g} \mathrm{~L}^{-1}$.

In nature, Arthrospira is found in permanent or temporary water bodies at relatively high temperatures. The optimal temperature for the cultivation of this organism is about $36^{\circ} \mathrm{C}[34,42]$, but many studies at $30^{\circ} \mathrm{C}$ can also be found. A detailed study on the response of a Spirulina strain marked M-2 was performed by Torzillo and Vonshak [43] and the optimal temperature for photosynthesis was $35^{\circ} \mathrm{C}$. However, many Arthrospira strains differ in their optimal growth temperature as well as in their sensitivity to extreme values. Vonshak [8] tested three different strains, one with a relatively low temperature optimum of 30-32 ${ }^{\circ} \mathrm{C}$, while another grew well at a temperature of up to $40-42{ }^{\circ} \mathrm{C}$.

Without a doubt, light is the most important factor affecting photosynthetic organisms. Spirulina, like many other algae grown photoautotrophically, depends on light as its main energy source. Zarrouk [34] was the first to study the response of Arthrospira maxima to light and concluded that growth rate reached a maximum when cultures were grown under a light irradiance between 340-400 $\mu \mathrm{mol}$ photon $\mathrm{m}^{2} \mathrm{~s}^{-1}$. However, the study of Bocci et al. [44] showed that growth of $A$. fusiformis strain M2 became light-saturated in the range of $150-200 \mathrm{~m}$ mol photon $\mathrm{m}^{2} \mathrm{~s}^{-1}$. This value for irradiance is about one order of magnitude less than recorded outdoors in summer days (1850-2000 m mol photon $\mathrm{m}^{2} \mathrm{~s}^{-1}$ ). Chen et al. [45] observed that the maximum biomass production and biomass productivity of Arthrospira platensis increased with increasing light intensity from 100 to $700 \mu \mathrm{mol}$ photons $\mathrm{m}^{-2} \mathrm{~s}^{-1}$ while they remained nearly unchanged when the light intensity was higher than $900 \mu \mathrm{mol}$ photons $\mathrm{m}^{-2} \mathrm{~s}^{-1}$, which may be related to excessive illumination that would inhibit the biomass production and $\mathrm{CO}_{2}$ fixation efficiency [46]. Indeed, photoinhibition is defined as a loss of photosynthetic capacity due to damage caused by photon flux densities (PFD) in excess of that required to saturate photosynthesis. The phenomenon of photoinhibition in laboratory Arthrospira cultures was first studied by Kaplan [47], who observed a reduction in the photosynthetic activity when cells were exposed to high light. However, different strains may differ in their sensitivity to the light stress [8]. This difference could be due to a different rate of turnover of a specific protein, D1, which is part of PS II. The different response of strains to a photoinhibitory stress may thus have a genotypic origin, but can also arise from growth conditions. Indeed, cultures grown at high light intensity exhibit a higher resistance to photoinhibition, showing that an adaptation mechanism exists, probably explaining why outdoor cultivated strains can resist many intense irradiances.

Finally, regarding nitrogen source, Arthrospira strains can use different ones, even if the most widely used are nitrates. Nitrates enter the cells by a specific transporter (NRT type), are reduced into nitrites by nitrate reductase, and are further reduced into ammonium by nitrite reductase [48]. Ammonium assimilation appears to be more energetically favorable as there is no need for reduction steps, and is then the preferred source at low concentration. However, at high $\mathrm{pH}$, ammonium is transformed into ammoniac, which has been demonstrated to be toxic for the cells $[49,50]$, with a toxicity degree depending on the amount of ammonium and the $\mathrm{pH}$ of the medium [51,52] and the cellular target being photosynthetic $[53,54]$. In some studies, urea has also been shown to be a possible nitrogen source for Arthrospira species [55]. 


\section{Environmental Stresses for Glycogen Accumulation}

The growth of Arthrospira platensis during the exponential phase is focused in protein production and diverts maximum carbon and energy into cell growth and reproduction, although, during the stationary phase (nutrient starvation) or under different stress conditions, glycogen is accumulated [56]. In these conditions, the carbon flow is diverted from protein synthesis to lipids, carbohydrates, and carotenoids, among other metabolic pathways to ensure cell viability. The effect of different stress factors on glycogen accumulation is scarcely studied, despite their high added value for biofuel production [57]. In the literature, different techniques can be found to enhance the glycogen production of Arthrospira platensis (Table 1). However, studies are sometimes difficult to compare, mainly due to the different cultivation conditions, strains used, and glycogen quantification methods. Moreover, in some studies, only total carbohydrates are quantified, and not specifically glycogen. Arthrospira strains also produce an exopolysaccharide (EPS), which remains bound to the cells and is supposed to protect cells from environmental stresses. Additionally, some low molecular weight carbohydrates (trehalose and glucosyl-glycerol) can be found [58] and are also part of the total carbohydrates.

\subsection{Light Intensity}

One of the most primitive needs of all photosynthetic organisms is the adaptation to the daily and seasonal changes in light intensities [59]. To photosynthetic organisms, light is not only a signal to diurnal and seasonal cycle, but also an energy source that is captured and secured when available [60].

Aikawa et al. [61] evaluated the biomass production and glycogen accumulation of Arthrospira platensis under different light intensities from 20 up to $700 \mu \mathrm{mol}$ photons $\mathrm{m}^{-2}$ $\mathrm{s}^{-1}$. The initial growth rates were found to be similar at 270 and $700 \mu \mathrm{mol}$ photons $\mathrm{m}^{-2}$ $\mathrm{s}^{-1}$, but it started to decrease after a few days for the lower irradiance. This decrease in growth rate might be attributed to self-shading of the culture. Regarding the glycogen accumulation, a similar tendency was observed at 50 and $270 \mu \mathrm{mol}$ photons $\mathrm{m}^{-2} \mathrm{~s}^{-1}$ as glycogen content increased from $18 \%$ to $40 \%$ of cell dry weight after $12 \mathrm{~h}$ and decreased to the initial contents after three days. However, for higher light intensity $(700 \mu \mathrm{mol}$ photons $\mathrm{m}^{-2} \mathrm{~s}^{-1}$ ), the amount of glycogen reached up to $50 \%$ of cell dry weight. Yoshikawa et al. [59] conducted a metabolic simulation based on experimental data of the production of glycogen for further ethanol production based on Arthrospira platensis biomass. They observed a positive correlation of the glycogen content with the increasing light intensity, reaching 42\% DW for $250 \mu \mathrm{mol}$ photons $\mathrm{m}^{2} \mathrm{~s}^{-1}$. In 2019, Phelippe et al. [56] performed a meta-bibliographic analysis focused on glycogen and EPS production by Arthrospira, showing an increase in glycogen content with light intensity. Based on the literature, glycogen accumulation at high light intensity $\left(>200 \mu \mathrm{mol}\right.$ photons $\left.\mathrm{m}^{-2} \mathrm{~s}^{-1}\right)$ is about $45 \%$ DW (between 42 and 65\% DW depending on studies), while it remains below 20\% DW for lower irradiances. Additionally, as light intensity was found to be a key parameter for glycogen and EPS modulation, these authors also performed experiments at four irradiances (100, 400, 800, and $1200 \mu \mathrm{mol}$ photons $\mathrm{m}^{-2} \mathrm{~s}^{-1}$ ) and calculated EPS/glycogen ratios, established respectively at 3.1, 1.79, 1.54, and 0.64. This decrease in EPS/glycogen ratio can thus suggest a redirection of the carbon flux toward glycogen while increasing the light. 
Table 1. Glycogen accumulation strategies for Arthrospira platensis.

\begin{tabular}{|c|c|c|c|c|c|}
\hline Enhancement Technique & Carbohydrates & Biomass & Culture Conditions & Observations & Reference \\
\hline Light intensity & Glycogen (45\% DW) & $1.6 \mathrm{~g} \mathrm{~L}^{-1}$ & $\begin{array}{l}\text { Light intensity: } 700 \mu \mathrm{mol} / \mathrm{m}^{2} / \mathrm{s}, \\
\text { temperature: } 30^{\circ} \mathrm{C} \text {, volume: } 250 \mathrm{~mL} \text {, } \\
\text { time: } 5 \text { days, } 100 \mathrm{rpm}\end{array}$ & $\begin{array}{l}\text { Effect of different light intensities on the } \\
\text { production of glycogen of A. platensis 50, } \\
\qquad 270,700 \mu \mathrm{mol} / \mathrm{m}^{2} / \mathrm{s}\end{array}$ & [62] \\
\hline Light intensity & $\begin{array}{c}\text { EPS/glycogen ratios }(3.1 \\
1.79,1.54,0.64)\end{array}$ & $\begin{array}{c}6.810^{-3}, 1.810^{-2}, 2.9 \\
10^{-2}, 3.110^{-2} \mathrm{~g} \mathrm{~L}^{-1} \mathrm{~h}^{-1}\end{array}$ & $\begin{array}{c}\text { Light intensity: } 100,400,800 \text { and } 1200 \\
\mu \mathrm{mol} / \mathrm{m}^{2} / \mathrm{s} \text {, temperature: } 35^{\circ} \mathrm{C} \text {, Time: } \\
12 \text { days, } 1.3 \mathrm{~L} \text {, Aeration: } \mathrm{CO}_{2} 1 \% \text {, Flow: } \\
11 \mathrm{~mL} \mathrm{~min}^{-1}\end{array}$ & $\begin{array}{l}\text { Effect of different light intensities on the } \\
\text { glycogen and EPS production of } A \text {. } \\
\text { platensis, analysis of EPS composition. } \\
100,400,800 \text { and } 1200 \mu \mathrm{mol} / \mathrm{m}^{2} / \mathrm{s}\end{array}$ & [63] \\
\hline Nitrogen deficiency & Glycogen $\left(1.03 \mathrm{~g} \mathrm{~L}^{-1}\right)$ & $1.6 \mathrm{~g} \mathrm{~L}^{-1}$ & $\begin{array}{l}\text { Light intensity: } 700 \mu \mathrm{mol} / \mathrm{m}^{2} / \mathrm{s}, \\
\text { temperature: } 30{ }^{\circ} \mathrm{C} \text {, volume: } 250 \mathrm{~mL} \text {, } \\
\text { time: } 5 \text { days, } 100 \mathrm{rpm}\end{array}$ & $\begin{array}{c}\text { Nitrate: } 3 \mathrm{mM} \text {, Light intensity }(50,270, \\
\left.700 \mu \mathrm{mol} / \mathrm{m}^{2} / \mathrm{s}\right)\end{array}$ & [61] \\
\hline Nitrogen deficiency & $\begin{array}{l}\text { Carbohydrates }(73.2 \% \\
\text { DW) }\end{array}$ & $0.7 \mathrm{~g} \mathrm{~L}^{-1}$ & $\begin{array}{l}\text { Light intensity: } 40 \mu \mathrm{mol} / \mathrm{m}^{2} / \mathrm{s}, \\
\text { light:dark cycle } 14 \mathrm{~h}: 10 \mathrm{~h} \text {, temperature: } \\
28{ }^{\circ} \mathrm{C} \text {, volume: } 200 \mathrm{~mL} \text {, time: } 5 \text { days }\end{array}$ & $\mathrm{NaNO}_{3}: 15 \mathrm{mg} / \mathrm{L}$ & {$[31]$} \\
\hline Nitrogen deficiency & Carbohydrates (74\% DW) & $0.66 \mathrm{~g} \mathrm{~L}^{-1}$ & $\begin{array}{l}\text { Light intensity: } 100 \mu \mathrm{mol} / \mathrm{m}^{2} / \mathrm{s}, \\
\text { temperature: } 20^{\circ} \mathrm{C} \text {, volume: } 2000 \mathrm{~mL} \text {, } \\
\text { time: } 9 \text { days, light/dark cycle } 16 / 8, \\
\text { bubbling: } 0.2 \mu \mathrm{m} \text {-filtered air }\end{array}$ & $\begin{array}{c}\mathrm{NaNO}_{3}: 20 \mathrm{mg} / \mathrm{L} \text {, biomass concentrated } \\
15 \text { times by gravity settling }\end{array}$ & [29] \\
\hline Nitrogen deficiency & Carbohydrates (64.3\%) & $27.5 \mathrm{~g} / \mathrm{m} 2 / \mathrm{d}$ & $\begin{array}{c}\text { Natural daylight, temperature: } 25-35^{\circ} \mathrm{C} \text {, } \\
\text { volume: } 180 \mathrm{~m}^{3} \text {, time: } 90 \mathrm{~h}\end{array}$ & Nitrate: $4.7 \mathrm{mg} / \mathrm{L}$ & [65] \\
\hline Nitrogen deficiency & Glycogen $(63.2 \%)$ & $1.1 \mathrm{~g} \mathrm{~L}^{-1}$ & $\begin{array}{l}\text { Light intensity: } 50 \mu \mathrm{mol} / \mathrm{m}^{2} / \mathrm{s}, \\
\text { temperature: } 30^{\circ} \mathrm{C} \text {, volume: } 250 \mathrm{~mL} \text {, } \\
\text { time: } 7 \text { days, agitation: } 100 \mathrm{rpm}\end{array}$ & $\begin{array}{l}\mathrm{NaNO}_{3}: 29.4 \mathrm{mM} \text {, there was no } \\
\text { difference between the medium with } \\
\text { and without nitrogen depletion }\end{array}$ & [66] \\
\hline Nitrogen deficiency & $\begin{array}{c}\text { Total sugars }(10 \mu \mathrm{g} / \mathrm{mg} \\
\text { DW })\end{array}$ & - & $\begin{array}{l}\text { Light intensity: } 43 \mu \mathrm{mol} / \mathrm{m}^{2} / \mathrm{s} \text {, } \\
\text { temperature: } 30^{\circ} \mathrm{C} \text {, Time: } 168 \mathrm{~h}\end{array}$ & Nitrate free Zarrouk medium & [67] \\
\hline
\end{tabular}


Table 1. Cont.

\begin{tabular}{|c|c|c|c|c|c|}
\hline Enhancement Technique & Carbohydrates & Biomass & Culture Conditions & Observations & Reference \\
\hline Phosphorus deficiency & Glycogen $(70 \% \mathrm{DW})$ & $0.6 \mathrm{~g} \mathrm{~L}^{-1}$ & $\begin{array}{c}\text { Light intensity: } 100 \mu \mathrm{mol} / \mathrm{m}^{2} / \mathrm{s}, \\
\text { temperature: } 35^{\circ} \mathrm{C} \text {, volume: } 500 \mathrm{~mL} \text {, } \\
\text { time: } 96 \mathrm{~h}\end{array}$ & $\begin{array}{l}\text { The control amounts of glycogen and } \\
\text { biomass were: } 0.15 \mathrm{~g} / \mathrm{g} \text { DW and } 1.3 \mathrm{~g} / \mathrm{L} \\
\text { DW respectively. Also, flocculation } \\
\text { capability under nutrient starvation }\end{array}$ & [64] \\
\hline Phosphorus deficiency & $\begin{array}{l}\text { Carbohydrates }(63.1 \% \\
\text { DW) }\end{array}$ & $1.8 \mathrm{~g} \mathrm{~L}^{-1}$ & $\begin{array}{c}\text { Light intensity: } 120 \mu \mathrm{mol} / \mathrm{m}^{2} / \mathrm{s}, \\
\text { temperature: } 30^{\circ} \mathrm{C} \text {, volume: } 500 \mathrm{~mL} \text {, } \\
\text { time: } 7 \text { days, Aeration: Filtered air flow: } \\
0.2 v / v \text { min }\end{array}$ & $\mathrm{K}_{2} \mathrm{HPO}_{4}: 20 \mathrm{mg} / \mathrm{L}$ & [32] \\
\hline Phosphorus deficiency & Carbohydrates (65\% DW) & - & $\begin{array}{c}\text { Light intensity: } 20 \mu \mathrm{mol} / \mathrm{m}^{2} / \mathrm{s}, \\
\text { temperature: } 30^{\circ} \mathrm{C} \text {, time: } 27 \text { days, } \\
\text { volume: } 250 \mathrm{~mL} \text {, Aeration: Filtered air } \\
\text { flow: } 0.4 v / v \mathrm{~min}\end{array}$ & $\begin{array}{c}\mathrm{K}_{2} \mathrm{HPO}_{4}: 2 \mathrm{mg} / \mathrm{g} \text { of biomass } \\
\text { (intracellular phosphorus), } \mathrm{C} / \mathrm{N} \text { ratio } \\
\text { increased from } 4.6 \text { to } 12.2\end{array}$ & {$[32]$} \\
\hline Sodium stress & $\begin{array}{l}\text { Carbohydrates }(53.4 \% \\
\text { DW) }\end{array}$ & $2.1 \mathrm{~g} \mathrm{~L}^{-1}$ & $\begin{array}{c}\text { Light intensity: } 8000 \text { lux, temperature: } \\
27^{\circ} \mathrm{C} \text {, volume: } 100 \mathrm{~mL} \text {, time: } 7 \text { days, } \mathrm{pH} \text { : } \\
\text { 9.8, Aeration: } 15 \% \mathrm{CO}_{2} v / v \text { flow: } 30 \\
\mathrm{~mL} / \mathrm{min}\end{array}$ & $\begin{array}{c}\mathrm{NaCl}: 0.5 \mathrm{~mol} / \mathrm{L} \text { related to seawater } \\
\text { concentration }\end{array}$ & [26] \\
\hline Sodium stress & Carbohydrates (31\%DW) & $128 \mathrm{mg} / \mathrm{L} / \mathrm{d}$ & $\begin{array}{l}\text { Light intensity: } 80 \mu \mathrm{mol} / \mathrm{m} 2 / \mathrm{s}, \\
\text { temperature: } 30^{\circ} \mathrm{C} \text {, Time: } 10 \text { days, } \\
\text { volume: } 8000 \mathrm{~mL} \text {, Aeration: Filtered air, } \\
\text { Flow: } 0.1 \mathrm{v} / \mathrm{min} \text {, Air bubble size: } 3 \mathrm{~mm}\end{array}$ & 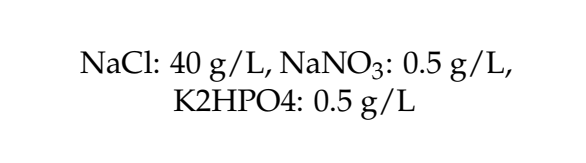 & {$[61]$} \\
\hline Sulphur deficiency & Glycogen $(68 \% \mathrm{DW})$ & $1.3 \mathrm{~g} \mathrm{~L}^{-1}$ & $\begin{array}{c}\text { Light intensity: } 100 \mu \mathrm{mol} / \mathrm{m}^{2} / \mathrm{s}, \\
\text { temperature: } 35^{\circ} \mathrm{C} \text {, volume: } 500 \mathrm{~mL} \text {, } \\
\text { time: } 96 \mathrm{~h}\end{array}$ & $\begin{array}{l}\text { The control amounts of glycogen and } \\
\text { biomass were: } 0.15 \mathrm{~g} / \mathrm{g} \text { DW and } 1.3 \mathrm{~g} / \mathrm{L} \\
\text { DW, respectively. Also, flocculation } \\
\text { capability under nutrient starvation }\end{array}$ & {$[64]$} \\
\hline Sulphur deficiency & $\begin{array}{l}\text { Carbohydrates }(61 \\
\mathrm{mg} / \mathrm{L} / \mathrm{d})\end{array}$ & $134 \mathrm{mg} / \mathrm{L} / \mathrm{d}$ & $\begin{array}{l}\text { Light intensity: } 2500 \text { lux, temperature: } \\
30^{\circ} \mathrm{C} \text {, volume: } 750 \mathrm{~mL} \text {, time: } 20 \text { days }\end{array}$ & $\begin{array}{l}\text { Different parameters where evaluated: } \\
\text { sulfur, nitrate, phosphorous } \\
\text { concentrations }\end{array}$ & {$[68]$} \\
\hline
\end{tabular}




\subsection{Nitrogen Depletion}

The deficiency of nitrogen in the culture media affects biomass production but significantly enhances the production of energy-rich components like lipids and carbohydrates as a response to adverse conditions like starvation or environmental stress [69]. The proportion of carbohydrates in Arthrospira platensis cells can reach up to $50 \%$ dry weight (DW) by optimizing the cultivation conditions [17]; some studies have even reached $60 \%$ DW of glycogen under the N-limitation condition [31]. Under nitrogen starvation, the flow of the photosynthetically fixed carbon is diverted from the protein synthesis metabolic pathway to carbohydrates or lipids [57]. Interestingly, Aikawa et al. [61] demonstrated that complete nitrogen starvation is not required, as glycogen accumulation was stimulated by using $3 \mathrm{mM}$ of nitrate. This finding is of interest for industrial scale production, as a limitation is sufficient to promote the synthesis, thus opening the possibility of producing glycogen in continuous mode.

In 2013, Hasunuma et al. [64] compared the glycogen and protein content of Arthrospira in replete and depleted nitrate conditions. In the presence of nitrate, the glycogen and protein contents remained nearly constant at $\sim 15 \%$ DW and $\sim 50 \%$ DW, respectively. In contrast, in the absence of nitrate, the glycogen content increased to $63.2 \%$ DW while the protein content decreased to $15.4 \%$. Analyzing the metabolic intermediates, they observed that shifting the cyanobacterial cells into nitrogen depletion and cultivating them for $72 \mathrm{~h}$ resulted in global metabolic modifications that involved reductions in the levels of several free amino acids (aspartate, glutamate, and glutamine), and increased in the levels of organic acids (2-ketoglutarate, malate, and succinate). Time-course profiling of metabolites demonstrated transient increases in the levels of other amino acids (glycine, histidine, isoleucine, leucine, methionine, phenylalanine, proline, threonine, and tyrosine). Such transient increases might be caused by protein hydrolysis and subsequent assimilation of these amino acids into glycogen via gluconeogenesis. In another study, Depraetere et al. [29] observed an increase in total carbohydrates (from $14 \%$ DW to $74 \%$ DW) and a decrease in protein content (from $37 \%$ DW to $10 \%$ DW). Transcriptomic and proteomic analysis indicated that the $\mathrm{N}$-limited condition induced a downregulation of de novo protein synthesis. In addition, photosynthetic energy production and carbon fixation were both downregulated, while glycogen synthesis was upregulated. The fact that glycogen synthesis has a lower energy demand than protein synthesis might explain why Arthrospira is able to achieve a similar biomass productivity under $\mathrm{N}$-limited as under $\mathrm{N}$-replete conditions, despite the fact that photosynthetic energy production was impaired by $\mathrm{N}$ limitation.

As demonstrated for other cyanobacteria [70], the proteins first degraded by A. platensis seem to be their light-harvesting apparatus, phycobilisome, to provide nitrogen when exogenous nitrogen is limited. Although the precise role that glycogen plays in cyanobacteria remains unclear, it has been suggested that the accumulation of glycogen by cyanobacteria may be advantageous during starvation periods, providing both a stored source of energy and a carbon surplus [69].

\subsection{Phosphorous Depletion}

The glycogen synthesis in Arthrospira platensis is strictly regulated by the amount of phosphorous in the cell, and the enzyme ADP-glucose pyrophosphorylase is responsible for producing ADP-Glc, which is the glucosyl donor for the elongation of the $\alpha-1,4$-glucosidic chain to synthesize glycogen [71]. The enzymatic reaction of the ADP-glucose pyrophosphorylase is ATP + Glc-1-phosphate $\leftrightarrow$ ADP-Glc + inorganic pyrophosphate (Pi); this enzymatic reaction in cyanobacteria is regulated positively by the 3-phosphoglycerate (3-PGA) and inhibited by Pi. If the concentration of inorganic phosphorus is low, the synthesis of glycogen is stimulated, as shown by [32], in phosphorus starvation conditions. This has also been observed by Arias et al. [72] with mixed cyanobacterial cultures, for which the glycogen accumulation was enhanced, obtaining up to $47 \%$ of total carbohydrate content. In addition, Klanchui et al. [62] observed that the amount of biomass and glycogen 
produced by Arthrospira platensis in different scenarios of starvation $\left(\mathrm{NO}^{3-}, \mathrm{PO}_{4}{ }^{3-}\right.$, and $\mathrm{SO}_{4}{ }^{2-}$ ). In this case, comparing phosphorous starvation with the other scenarios, it did not present a significant difference in the biomass production compared to the control, while an increase in the production of glycogen was observed, reaching up to $30 \% \mathrm{DW}$ of glycogen content after $18 \mathrm{~h}$ of culture. This was also predicted by the simulations and was consistent with the results obtained by experiments where the simulated fluxes had no significant differences. Another example of the enhancement in the production of glycogen via phosphorus deprivation is in Monshupanee and Incharoensakdi [28], where the total glycogen content increased from 15.1 to $28.9 \%$ DW. A similar result was also observed with nitrogen deprivation. Nevertheless, the biomass production was not compromised. Another interesting result was obtained by El-Shouny et al. [66], who increased the total carbohydrates of Arthrospira platensis by 300\%, when the phosphate concentration was half-reduced during the culture (from $0.5 \mathrm{~g} / \mathrm{L}$ to $0.25 \mathrm{~g} / \mathrm{L}$ ). In summary, the reduction of phosphorous to enhance the glycogen content of Arthrospira platensis seems like a good strategy, assuring both high glycogen content and biomass production. Therefore, this approach would increase the overall yield of the bioethanol production.

\subsection{Sulfur Depletion}

Sulfur is known to be an essential element for amino acids, lipid biosynthesis, and the whole metabolism in general, where there is evidence that different concentrations of this element can modify the metabolism of cyanobacteria and its production of glycogen and other bioactive molecules [73]. Kumaresan et al. [74] analyzed the transcriptome profile of different genes involved in various sulfur-dependent pathways in Arthrospira sp and observed downregulated genes in amino acid biosynthesis, protein folding, and rRNA binding, whereas genes involved in carbohydrate metabolism, DNA repair, among others, were upregulated during sulfur-stress conditions. El-Shouny et al. [66] also demonstrated that reducing the sulfur concentration in media significantly modified Arthrospira platensis carbohydrate accumulation without affecting the growth or biomass productivity. The reduction of $50 \%$ in $\mathrm{K}_{2} \mathrm{SO}_{4}$ enhanced carbohydrate production by $25 \%$; interestingly, the further reduction of $\mathrm{K}_{2} \mathrm{SO}_{4}$ by $100 \%$, reached an enhancement of $380 \%$ compared to the control $\left(1 \mathrm{~g} / \mathrm{L}\right.$ of $\left.\mathrm{K}_{2} \mathrm{SO}_{4}\right)$, while the biomass concentrations did not represent a significative difference (134 and $136 \mathrm{mg} \mathrm{L}^{-1} \mathrm{~d}^{-1}$, respectively). However, lipids and protein productivities were decreased as sulfur concentration decreased by half $(40 \%$ and $44 \%$, respectively), meaning that the modification in the concentration of sulfur can be oriented depending on the final product of interest. Klanchui et al. [60] analyzed the effect of depletion of $\mathrm{NO}^{3-}, \mathrm{PO}_{4}{ }^{3-}$, and $\mathrm{SO}_{4}{ }^{2-}$ to obtain a glycogen-enriched biomass of Arthrospira platensis, where it seems that the reduction in $\mathrm{SO}_{4}{ }^{2-}$ increased the yield of glycogen production $300 \%$ compared to the control after just $24 \mathrm{~h}$ of incubation, nevertheless, after $96 \mathrm{~h}$ of incubation, the amounts of glycogen obtained were similar to $\mathrm{NO}^{3-}$ depletion $(60 \%$ DW). Analyzing the sulfur depletion, it seems similar to the phosphate strategy, which is the enhancement of glycogen production without reducing the amount of biomass produced during the culture, so the combination of both strategies could be a new approach in designing new culture media to obtain a glycogen-enriched biomass of Arthrospira platensis.

\subsection{Salinity Effect}

High salt concentrations generate two major problems for living systems: first, low water potential results in a loss of water accumulating osmotically-active compounds, and second, the high ionic strength of the surrounding medium results in a continuous influx of inorganic ions (mainly $\mathrm{Na}^{+}$and $\mathrm{Cl}^{-}$) [58]. Most organisms (including cyanobacteria) limit the cytoplasmic ionic strength to rather low concentrations as most intracellular macromolecules are sensitive to inorganic ions. There are two strategies that cyanobacteria follow to mitigate the osmotic pressure: first, to pump out ions, especially $\mathrm{Na}^{+}$and $\mathrm{Cl}^{-}$, and second, to produce solutes that are compatible with the cell metabolism [75]. Based on their chemical structure, compatible solutes can be divided into various groups: carbohydrates, 
polyols, heterosides, amino acids, and their derivatives [58]. In Arthrospira platensis, one of the main solutes produced to mitigate osmotic pressure is the production of trehalose, glucosyl-glycerol, and glucosyl-glycerate.

Increases in sodium concentration have been commonly observed in the literature as a strategy to accumulate carbohydrates in Arthrospira platensis, especially glycogen [26]. An increase in osmotic stress can induce Arthrospira cells to synthesize osmoprotectants (trehalose, glucosyl-glycerol, and glucosyl-glycerate) [76], and the accumulation of these low molecular weight carbohydrates increases the total amount of sugars, thus enhancing the bioethanol production. In addition, Chentir et al. [57] found that the $\mathrm{NaCl}$ (from 1 up to $40 \mathrm{~g} / \mathrm{L}$ ) exerted a positive effect on both the carbohydrate and lipid contents of Arthrospira platensis.

The addition of $\mathrm{NaCl}$ in the culture medium could also affect the transcriptional regulation of the metabolism of different cyanobacteria via cAMP as a signaling molecule [59] as there is evidence pointing that this modification of the metabolism can enhance glycogen production [77].

\subsection{Combined Stresses}

Different stresses can allow for the glycogen content of Arthrospira biomass to be enhanced. Even if studies are quite scarce, some authors have also tested combining two of these conditions in order to further increase the glycogen content. Aikawa et al. [61] proposed combining high light intensity and nitrogen depletion, allowing them to reach over $65 \%$ DW, whereas it was only $18 \%$ DW for the control and $45 \%$ DW for nitrogen depletion only.

The mix of nitrogen starvation and osmotic stress can impact the total amount of the biomass produced; nevertheless, this is compensated for by the increase in glycogen produced at the end of the culture. Ding et al. [26] observed an increase in the total carbohydrate content of Arthrospira platensis of $61.5 \%$ using nitrogen starvation and a high level of $\mathrm{CO}_{2}\left(15 \%\right.$ of $\left.\mathrm{CO}_{2}\right)$ as well as an increase of $228.6 \%$ using nitrogen starvation and osmotic stress $(0.5 \mathrm{M}$ of $\mathrm{NaCl})$ reaching $58 \% \mathrm{DW}$ of total carbohydrate content compared to the control without $\mathrm{CO}_{2}$ nor $\mathrm{NaCl}$.

\section{Techno-Economical Considerations}

Production of ethanol through biological fermentation of sugars extracted from sugarcane [78] or corn and wheat $[79,80]$ (1st generation biofuel) is technically matured and commercially available. For instance, global leaders in fuel ethanol production such as the United States and Brazil produced about $~ 57.7$ billion L and 27.6 billion L of bioethanol in 2019 [80]. Liquefaction of the starch fraction is accomplished by adding hydrolytic enzymes ( $\alpha$-amylases) at temperatures of around $90{ }^{\circ} \mathrm{C}$. After the liquefaction step, the starch molecules are further hydrolyzed by the addition of glucoamylases. This produces sugars, which are readily fermented by yeast (e.g., Saccharomyces cerevisiae) to ethanol. The main co-product is usually animal feed, consisting of the remaining fraction of the raw material, mainly proteins and fibers [81]. However, this feedstock is competing with food, making it controversial.

On the other hand, lignocellulosic material such as sugarcane bagasse (SCB), oil palm empty fruit bunches (OPEFB), wheat straw, rice straw, corn straw, and soybean bagasse have been proposed as a viable alternative to produce liquid biofuels (2nd generation), but the technology is still under development as it is still difficult to reach high ethanol concentrations during fermentation. Lignocellulosic materials contain about $50-60 \%$ of carbohydrates in the form of cellulose (made up of glucose) and hemicellulose (consisting of various pentose and hexose sugars), which may be fermented to ethanol, and 20 $35 \%$ lignin. The separation of these compounds requires strong pretreatments, which can be chemical, thermochemical, or biological with the use of cellulases. Even if the efficiency of some methods have been demonstrated at the lab-scale, the main limitation in the industrial development of such processes remains the production costs linked to 
their complexity. Indeed, the main locks are (1) the complex structure of lignocellulosic materials, making them recalcitrant to hydrolysis, requiring strong pre-treatment and the use of expensive cellulases; (2) the presence of various hexose and pentose sugars in hemicellulose, making fermentation more difficult than from glucose; and (3) the presence of various compounds that inhibit the fermenting organism. Even if some techno-economic evaluations are available in the literature, it is still difficult to evaluate the production costs of such a bioethanol, as large variations in the process design (different pre-treatments and conversion methods, various types of raw materials ... ) and in the assumptions underlying the techno-economic evaluations have been observed.

As the glycogen is a polymer of glucose, just like starch, the conversion of glycogen into bioethanol would thus be closed to a 1st generation one from a process point of view, and high cost pre-treatments will not be required. A comparison of simplified process diagrams is proposed in Figure 1. However, biomass production costs have to be taken into account. In a recent review, [82] estimated the production costs of Spirulina dry biomass at $5.1 \mathrm{USD} \mathrm{kg}^{-1}$ assuming a plant with a productivity of 750,000 $\mathrm{kg} \mathrm{year}^{-1}$. This feedstock price appears then to be much greater than corn or sugar-cane, but several advantages of using Arthrospira species exist such as: (1) the high growth rate and volumetric productivity as it has a very short harvesting cycle and a production that goes nearly all year (whereas higher plants have generally a one year growth cycle); (2) being able to grow on salt or wastewater streams thereby reducing freshwater use; (3) not competing with arable land for food production; (4) $\mathrm{CO}_{2}$ capture via photosynthesis, thereby mitigating greenhouse gas emissions; (5) the high glycogen content in the biomass (thus fermentescible sugars), thus leading to potentially better conversion yields; (6) mass cultivation and industrial plants are already implemented, thus the technology is already mature; and (7) other compounds can be extracted prior to bioethanol production such as phycocyanin, allowing for an increase in value and reduce production costs. 


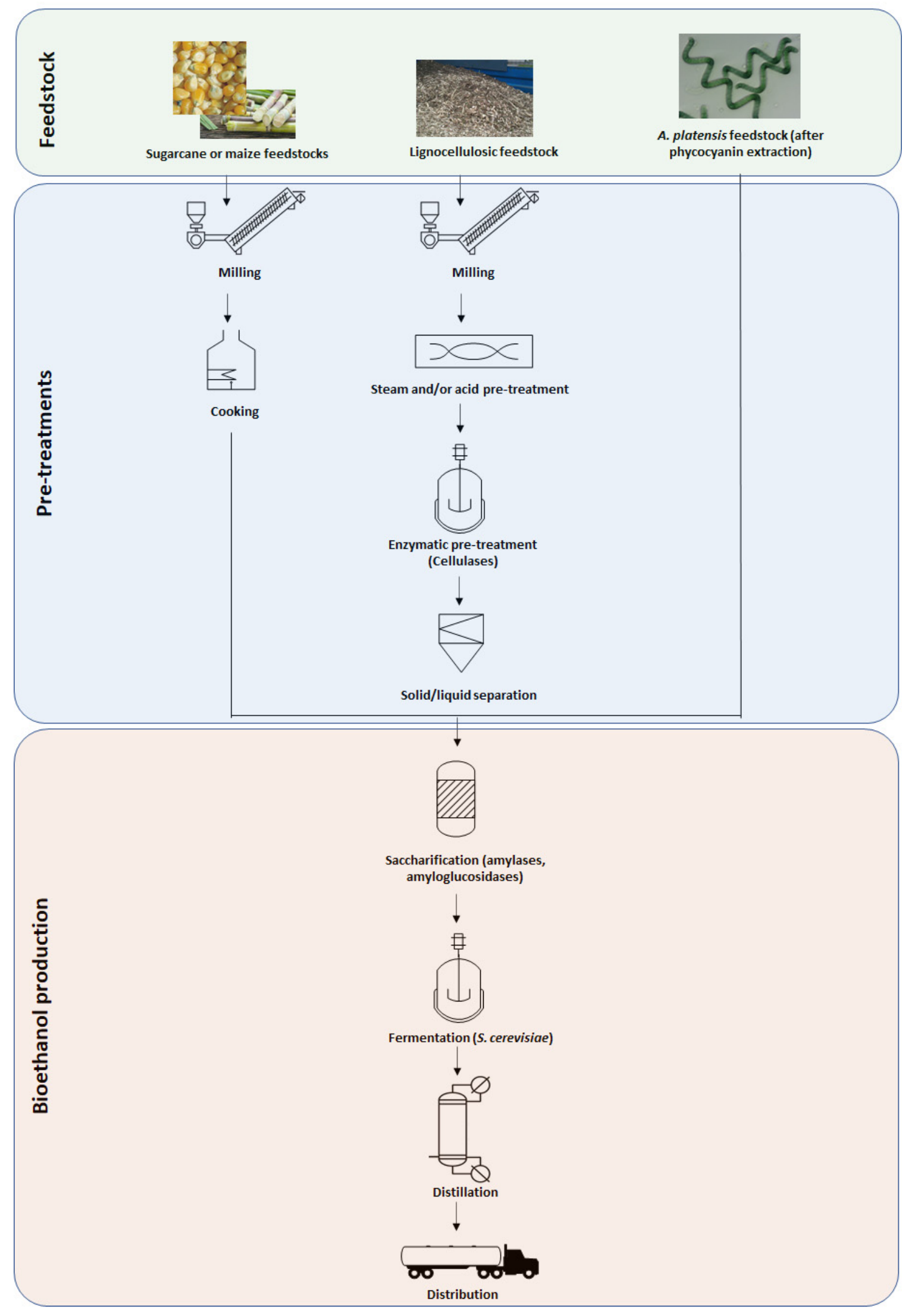

Figure 1. Comparison of process flow diagrams for bioethanol production, depending on the feedstocks. 


\section{Conclusions}

Several studies have pointed out the importance of microalgae, especially Arthrospira platensis for bioprocesses in health, cosmetics, nutrition, and bioremediation, among others. This cyanobacterium has been exploited for the diversity and active ingredients in its compounds; nevertheless, its use for biofuel production is still an opportunity not exhausted to its full potential. This review aimed at the use of Arthrospira platensis for bioethanol production based on glycogen. Different strategies can be considered to enhance glycogen yields concerning the composition of the culture media and the culture conditions. However, for the utilization of cyanobacteria as a biofuel feedstock, maintenance of cell growth is also important to improve glycogen production because glycogen production should be estimated by multiplying the glycogen content per cell by cellular biomass production. Even if nutrient depletion promotes glycogen levels in the cells, the main drawback is the reduction in the biomass production. Therefore, attention must be paid that in most cases, two stage cultivation is required in order to first produce a sufficient amount of biomass, and then further induce glycogen accumulation.

The increase in glycogen in Arthrospira platensis can have a beneficial side effect, as the accumulation of glycogen is accompanied by an increase in the cellular density and sedimentation of the biomass [63]. This can be of great interest while producing glycogen at an industrial scale as it will facilitate downstream processing of the biomass.

Author Contributions: Writing-original draft preparation, E.G.B., C.L.; writing-review and editing, C.L.; supervision, C.L. All authors have read and agreed to the published version of the manuscript.

Funding: This research was funded by Auvergne Région in the frame of CPER MMaSyF.

Conflicts of Interest: The authors declare no conflict of interest.

\section{References}

1. Chiong, M.C.; Chong, C.T.; Ng, J.-H.; Lam, S.S.; Tran, M.-V.; Chong, W.W.F.; Jaafar, M.N.M.; Valera-Medina, A. Liquid biofuels production and emissions performance in gas turbines: A review. Energy Convers. Manag. 2018, 173, 640-658. [CrossRef]

2. Bala, J.D.; Lalung, J.; Al-Gheethi, A.A.S.; Norli, I. A review on biofuel and bioresources for environmental applications. In Renewable Energy and Sustainable Technologies for Building and Environmental Applications: Options for a Greener Future; Ahmad, M.I., Ismail, M., Riffat, S., Eds.; Springer International Publishing: Cham, Switzerland, 2016; pp. 205-225.

3. Sudhakar, K.; Mamat, R.; Samykano, M.; Azmi, W.; Ishak, W.; Yusaf, T. An overview of marine macroalgae as bioresource. Renew. Sustain. Energy Rev. 2018, 91, 165-179. [CrossRef]

4. Jambo, S.A.; Abdulla, R.; Azhar, S.H.M.; Marbawi, H.; Gansau, J.A.; Ravindra, P. A review on third generation bioethanol feedstock. Renew. Sustain. Energy Rev. 2016, 65, 756-769. [CrossRef]

5. Lima, G.M.; Teixeira, P.C.N.; Teixeira, C.M.L.L.; Filócomo, D.; Lage, C.L.S. Influence of spectral light quality on the pigment concentrations and biomass productivity of Arthrospira platensis. Algal Res. 2018, 31, 157-166. [CrossRef]

6. Scaife, M.A.; Merkx-Jacques, A.; Woodhall, D.L.; Armenta, R.E. Algal biofuels in Canada: Status and potential. Renew. Sustain. Energy Rev. 2015, 44, 620-642. [CrossRef]

7. Merlo, S.; Gabarrell Durany, X.; Pedroso Tonon, A.; Rossi, S. Marine microalgae contribution to sustainable development. Water 2021, 13, 1373. [CrossRef]

8. Vonshak, A. Physiology, Cell-Biology and Biotechnology; Taylor \& Francis: London, UK, 1997.

9. Masojídek, J.; Torzillo, G. Mass cultivation of freshwater microalgae. In Earth Systems and Environmental Sciences, 2nd ed.; Elsevier: Amsterdam, The Netherlands, 2014.

10. Cheng, J.; Zhu, Y.; Xu, X.; Zhang, Z.; Yang, W. Enhanced biomass productivity of Arthrospira platensis using zeolitic imidazolate framework-8 as carbon dioxide adsorbents. Bioresour. Technol. 2019, 294, 122118. [CrossRef] [PubMed]

11. Koyande, A.K.; Chew, K.W.; Rambabu, K.; Tao, Y.; Chu, D.-T.; Show, P.-L. Microalgae: A potential alternative to health supplementation for humans. Food Sci. Hum. Wellness 2019, 8, 16-24. [CrossRef]

12. Morone, J.; Alfeus, A.; Vasconcelos, V.; Martins, R. Revealing the potential of cyanobacteria in cosmetics and cosmeceuticals-A new bioactive approach. Algal Res. 2019, 41, 101541. [CrossRef]

13. Ma, Z.; Ahmed, F.; Yuan, B.; Zhang, W. Fresh living Arthrospira as dietary supplements: Current status and challenges. Trends Food Sci. Technol. 2019, 88, 439-444. [CrossRef]

14. Zhu, Y.; Cheng, J.; Zhang, Z.; Liu, J. Mutation of Arthrospira platensis by gamma irradiation to promote phenol tolerance and $\mathrm{CO}_{2}$ fixation for coal-chemical flue gas reduction. J. $\mathrm{CO}_{2}$ Util. 2020, 38, 252-261. [CrossRef] 
15. Poughon, L.; Laroche, C.; Creuly, C.; Dussap, C.-G.; Paille, C.; Lasseur, C.; Monsieurs, P.; Heylen, W.; Coninx, I.; Mastroleo, F.; et al. Limnospira indica PCC8005 growth in photobioreactor: Model and simulation of the ISS and ground experiments. Life Sci. Space Res. 2020, 25, 53-65. [CrossRef]

16. Nematollahi, M.A.; Laird, D.W.; Hughes, L.J.; Raeisossadati, M.; Moheimani, N.R. Effect of organic carbon source and nutrient depletion on the simultaneous production of a high value bioplastic and a specialty pigment by Arthrospira platensis. Algal Res. 2020, 47, 101844. [CrossRef]

17. Rubio, C.; Dominik-Jakubiec, M.; Paz, S.; Gutiérrez, Á.J.; González-Weller, D.; Hardisson, A. Dietary exposure to trace elements (B, Ba, $\mathrm{Li}, \mathrm{Ni}, \mathrm{Sr}$, and $\mathrm{V}$ ) and toxic metals ( $\mathrm{Al}, \mathrm{Cd}$, and $\mathrm{Pb}$ ) from the consumption of commercial preparations of Spirulina platensis. Environ. Sci. Pollut. Res. Int. 2021, 28, 22146-22155. [CrossRef]

18. Kałduńska, J.; Jakubczak, K.; Gutowska, I.; Dalewski, B.; Janda, K. Fluoride content in dietary supplements of spirulina (Arthrospira spp.) from conventional and organic cultivation. Fluoride 2020, 5, 469-476.

19. Cheng, J.; Xia, A.; Song, W.; Su, H.; Zhou, J.; Cen, K. Comparison between heterofermentation and autofermentation in hydrogen production from Arthrospira (Spirulina) platensis wet biomass. Int. J. Hydrogen Energy 2012, 37, 6536-6544. [CrossRef]

20. Lee, M.; Chen, Y.; Peng, T. Two-stage culture method for optimized polysaccharide production in Spirulina platensis. J. Sci. Food Agric. 2012, 92, 1562-1569. [CrossRef]

21. Mendoza, Á.; Morales, V.; Sánchez-Bayo, A.; Rodríguez-Escudero, R.; González-Fernández, C.; Bautista, L.F.; Vicente, G. The effect of the lipid extraction method used in biodiesel production on the integrated recovery of biodiesel and biogas from Nannochloropsis gaditana, Isochrysis galbana and Arthrospira platensis. Biochem. Eng. J. 2020, 154, 107428. [CrossRef]

22. Sydney, E.B.; Sturm, W.; de Carvalho, J.C.; Thomaz-Soccol, V.; Larroche, C.; Pandey, A.; Soccol, C.R. Potential carbon dioxide fixation by industrially important microalgae. Bioresour. Technol. 2010, 101, 5892-5896. [CrossRef]

23. Choi, Y.Y.; Patel, A.K.; Hong, M.E.; Chang, W.S.; Sim, S.J. Microalgae Bioenergy with Carbon Capture and Storage (BECCS): An emerging sustainable bioprocess for reduced $\mathrm{CO}_{2}$ emission and biofuel production. Bioresour. Technol. Rep. 2019, 7, 100270. [CrossRef]

24. Ho, S.-H.; Zhang, C.; Tao, F.; Zhang, C.; Chen, W.-H. Microalgal torrefaction for solid biofuel production. Trends Biotechnol. 2020, 38, 1023-1033. [CrossRef] [PubMed]

25. Pourkarimi, S.; Hallajisani, A.; Alizadehdakhel, A.; Nouralishahi, A. Biofuel production through micro- and macroalgae pyrolysis-A review of pyrolysis methods and process parameters. J. Anal. Appl. Pyrolysis 2019, 142, 104599. [CrossRef]

26. Ding, L.; Cheng, J.; Lu, H.; Yue, L.; Zhou, J.; Cen, K. Three-stage gaseous biofuel production combining dark hydrogen, photo hydrogen, and methane fermentation using wet Arthrospira platensis cultivated under high $\mathrm{CO}_{2}$ and sodium stress. Energy Convers. Manag. 2017, 148, 394-404. [CrossRef]

27. Serrà, A.; Artal, R.; García-Amorós, J.; Gómez, E.; Philippe, L. Circular zero-residue process using microalgae for efficient water decontamination, biofuel production, and carbon dioxide fixation. Chem. Eng. J. 2020, 388, 124278. [CrossRef]

28. Monshupanee, T.; Incharoensakdi, A. Enhanced accumulation of glycogen, lipids and polyhydroxybutyrate under optimal nutrients and light intensities in the cyanobacterium Synechocystis sp. PCC 6803. J. Appl. Microbiol. 2014, 116, 830-838. [CrossRef] [PubMed]

29. Depraetere, O.; Deschoenmaeker, F.; Badri, H.; Foubert, I.; Leys, N.; Wattiez, R.; Muylaert, K. Trade-Off between Growth and Carbohydrate Accumulation in Nutrient-Limited Arthrospira sp. PCC 8005 Studied by Integrating Transcriptomic and Proteomic Approaches. PLoS ONE 2015, 10, e0132461.

30. Arias, D.M.; García, J.; Uggetti, E. Production of polymers by cyanobacteria grown in wastewater: Current status, challenges and future perspectives. New Biotechnol. 2020, 55, 46-57. [CrossRef]

31. Yao, C.; Pan, Y.; Lu, H.; Wu, P.; Meng, Y.; Cao, X.; Xue, S. Utilization of recovered nitrogen from hydrothermal carbonization process by Arthrospira platensis. Bioresour. Technol. 2016, 212, 26-34. [CrossRef]

32. Markou, G. Alteration of the biomass composition of Arthrospira (Spirulina) platensis under various amounts of limited phosphorus. Bioresour. Technol. 2012, 116, 533-535. [CrossRef]

33. Nowicka-Krawczyk, P.; Mühlsteinová, R.; Hauer, T. Detailed characterization of the Arthrospira type species separating commercially grown taxa into the new genus Limnospira (Cyanobacteria). Sci. Rep. 2019, 9, 1-11. [CrossRef]

34. Zarrouk, C. Contribution à l'étude d'une Cyanophycée: Influence de Divers Facteurs Physiques et Chimiques sur la Croissance et la Photosynthèse de Spirulina Maxima. Ph.D. Thesis, Université de Paris, Paris, France, 1966.

35. Richmond, A.E. Microalgaculture. In CRC Critical Reviews in Biotechnology; CRC Press Inc.: Boca Raton, FL, USA, 1988 ; Volume 4.

36. Chojnacka, K.; Noworita, A. Evaluation of Spirulina sp growth in phototrophic, heterotrophic and mixotrophic cultures. Enzyme Microb. Technol. 2004, 34, 461-465. [CrossRef]

37. Cogne, G.; Lehmann, B.; Dussap, C.-G.; Gros, J.-B. Uptake of macrominerals and trace elements by the cyanobacterium Spirulina platensis (Arthrospira platensis PCC 8005) under photoautotrophic conditions: Culture medium optimization. Biotechnol. Bioeng. 2003, 81, 588-593. [CrossRef]

38. Belkin, S.; Boussiba, S. Resistance of Spirulina platensis to ammonia at high pH values. Plant Cell Physiol. 1991, 32, 953-958. [CrossRef]

39. Coleman, J.R.; Colman, B. Inorganic carbon accumulation and photosynthesis in a blue-green alga as function of external pH. Plant Physiol. 1981, 67, 917-921. [CrossRef] [PubMed] 
40. Grant, W.D.; Mwatha, W.E.; Jones, B.E. Alkaliphiles: Ecology, diversity and applications. FEMS Microbiol. Rev. 1990, 75, $255-270$. [CrossRef]

41. Iltis, A. Tolérance de salinité de Spirulina platensis (Gom.) Geitler, (Cyanophyta) dans les mares natronées du Kanem (Tchad). Cah ORSTOM Sér Hydrobiol. 1968, 2, 119-125.

42. Cornet, J.-F. Etude Cinétique et Energétique d'un Photobioréacteur. Etablissement d'un Modèle Structure. Applications à un Ecosystème clos Artificiel. Ph.D. Thesis, Université de Paris, Paris, France, 1992.

43. Torzillo, G.; Vonshak, A. Effect of light and temperature on the photosynthetic activity of the cyanobacterium Spirulina platensis. Biomass Bioenergy 1994, 6, 399-405. [CrossRef]

44. Bocci, F.; Ferrari, F.; Materassi, R.; Mannelli, D. Prime Ricerche Sulla Crescita di Spirulina platensis e Spirulina Maxima in Coltura Fotolimitata; Atti XIX Congr Naz Soc Ital Microbiol: Catania, Italy, 1980.

45. Chen, C.-Y.; Kao, P.-C.; Tsai, C.-J.; Lee, D.-J.; Chang, J.-S. Engineering strategies for simultaneous enhancement of C-phycocyanin production and $\mathrm{CO}_{2}$ fixation with Spirulina platensis. Bioresour. Technol. 2013, 145, 307-312. [CrossRef]

46. Soletto, D.; Binaghi, L.; Ferrari, L.; Lodi, A.; Carvalho, J.C.M.; Zilli, M.; Converti, A. Effects of carbon dioxide feeding rate and light intensity on the fed-batch pulse-feeding cultivation of Spirulina platensis in helical photobioreactor. Biochem. Eng. J. 2008, 39, 369-375. [CrossRef]

47. Kaplan, A. Photoinhibition in Spirulina platensis: Response of photosynthesis and $\mathrm{HCO}_{3}{ }^{-}$uptake capability to $\mathrm{CO}_{2}-$ depleted conditions. J. Exp. Bot. 1981, 32, 669. [CrossRef]

48. Flores, E.; Frías, J.E.; Rubio, L.M.; Herrero, A. Photosynthetic nitrate assimilation in cyanobacteria. Photosyn. Res. 2005, 83, 117-133. [CrossRef] [PubMed]

49. Boussiba, S. Ammonia uptake in the alkalophilic cyanobacterium Spirulina platensis. Plant Cell Physiol. 1989, 30, 303-308. [CrossRef]

50. Boussiba, S.; Gibson, J. Ammonia translocation in cyanobacteria. FEMS Microbiol. Rev. 1991, 88, 1-14.

51. Markou, G.; Vandamme, D.; Muylaert, K. Ammonia inhibition on Arthrospira platensis in relation to the initial biomass density and pH. Bioresour. Technol. 2014, 166, 259-265. [CrossRef] [PubMed]

52. Abeliovitch, A.; Azov, Y. Toxicity of ammonia to algae in sewage oxidation pounds. Appl. Environ. Microbiol. 1976, 31, 801-806. [CrossRef] [PubMed]

53. Dai, G.-Z.; Qiu, B.-S.; Forchhammer, K. Ammonium tolerance in the cyanobacterium Synechocystis sp. strain PCC 6803 and the role of the psbA multigene family. Plant Cell Environ. 2014, 37, 840-851. [CrossRef]

54. Drath, M.; Kloft, N.; Batschauer, A.; Marin, K.; Novak, J.; Forchhammer, K. Ammonia triggers photodamage of photosystem II in the cyanobacterium Synechocystis sp. strain PCC 6803. Plant Physiol. 2008, 147, 206-215. [CrossRef]

55. Avila-Leon, I.; Chuei-Matsudo, M.; Sato, S.; de Carvalho, J.C.M. Arthrospira platensis biomass with high protein content cultivated in continuous process using urea as nitrogen source. J Appl. Microbiol. 2012, 112, 1086-1094. [CrossRef]

56. Phélippé, M.; Gonçalves, O.; Thouand, G.; Cogne, G.; Laroche, C. Characterization of the polysaccharides chemical diversity of the cyanobacteria Arthrospira platensis. Algal Res. 2019, 38, 101426. [CrossRef]

57. Chentir, I.; Doumandji, A.; Ammar, J.; Zili, F.; Jridi, M.; Markou, G.; Ben Ouada, H. Induced change in Arthrospira sp. (Spirulina) intracellular and extracellular metabolites using multifactor stress combination approach. J. Appl. Phycol. 2018, 30, 1563-1574. [CrossRef]

58. Klähn, S.; Hagemann, M. Compatible solute biosynthesis in cyanobacteria. Environ. Microbiol. 2011, 13, 551-562. [CrossRef]

59. Yoshikawa, K.; Aikawa, S.; Kojima, Y.; Toya, Y.; Furusawa, C.; Kondo, A.; Shimizu, H. Construction of a Genome-Scale Metabolic Model of Arthrospira platensis NIES-39 and Metabolic Design for Cyanobacterial Bioproduction. PLoS ONE 2015, 10, e0144430.

60. Li, Y.; Horsman, M.; Wang, B.; Wu, N.; Lan, C.Q. Effects of nitrogen sources on cell growth and lipid accumulation of green alga Neochloris oleoabundans. Appl. Microbiol. Biotechnol. 2008, 81, 629-636. [CrossRef]

61. Aikawa, S.; Izumi, Y.; Matsuda, F.; Hasunuma, T.; Chang, J.-S.; Kondo, A. Synergistic enhancement of glycogen production in Arthrospira platensis by optimization of light intensity and nitrate supply. Bioresour. Technol. 2012, 108, 211-215. [CrossRef]

62. Klanchui, A.; Dulsawat, S.; Chaloemnegam, K.; Cheevadhanarak, S.; Prommeenate, P.; Meechai, A. An improved Genome-scale metabolic model of Arthrospira platensis C1 (iAK888) and its application in glycogen overproduction. Metabolites $2018,8,84$. [CrossRef] [PubMed]

63. Liu, Q.; Yao, C.; Sun, Y.; Chen, W.; Tan, H.; Cao, X.; Xue, S.; Yin, H. Production and structural characterization of a new type of polysaccharide from nitrogen-limited Arthrospira platensis cultivated in outdoor industrial-scale open raceway ponds. Biotechnol. Biofuels 2019, 12, 131-144. [CrossRef] [PubMed]

64. Hasunuma, T.; Kikuyama, F.; Matsuda, M.; Aikawa, S.; Izumi, Y.; Kondo, A. Dynamic metabolic profiling of cyanobacterial glycogen biosynthesis under conditions of nitrate depletion. J. Exp. Bot. 2013, 64, 2943-2954. [CrossRef] [PubMed]

65. Deschoenmaeker, F.; Bayon-Vicente, G.; Sachdeva, N.; Depraetere, O.; Cabrera Pino, J.C.; Leroy, B.; Muylaert, K.; Wattiez, R. Impact of different nitrogen sources on the growth of Arthrospira sp. PCC 8005 under batch and continuous cultivation-A biochemical, transcriptomic and proteomic profile. Bioresour. Technol. 2017, 237, 78-88. [CrossRef]

66. El-Shouny, W.; Sharaf, M.; Abomohra, A.E.-F.; Abo-Eleneen, M. Production enhancement of some valuable compounds of Arthrospira platensis. J. Bas. E Environ. Sci. 2015, 2, 74-85.

67. Kashith, M.; Keerthana, B.; Sriram, S.; Ramamurthy, V. Adenylate cyclase in Arthrospira platensis responds to light through transcription. Biochem. Biophy. Res. Com. 2016, 477, 297-301. [CrossRef] 
68. Karniol, B.; Wagner, J.R.; Walker, J.M.; Vierstra, R.D. Phylogenetic analysis of the phytochrome superfamily reveals distinct microbial subfamilies of photoreceptors. Biochem. J. 2005, 392, 103-116. [CrossRef] [PubMed]

69. Strange, R.E. Bacterial glycogen and survival. Nature 1968, 220, 606-607. [CrossRef] [PubMed]

70. Grossman, A.R.; Schaefer, M.R.; Chiang, G.G.; Collier, J.L. Environmental effects on the light-harvesting complex of cyanobacteria. J. Bacteriol. 1993, 175, 575-582. [CrossRef]

71. Ballicora, M.A.; Iglesias, A.A.; Preiss, J. ADP-Glucose pyrophosphorylase, a regulatory enzyme for bacterial glycogen synthesis. MMBR 2003, 67, 213-225. [CrossRef] [PubMed]

72. Arias, D.M.; Fradinho, J.C.; Uggetti, E.; García, J.; Oehmen, A.; Reis, M.A. Polymer accumulation in mixed cyanobacterial cultures selected under the feast and famine strategy. Algal Res. 2018, 33, 99-108. [CrossRef]

73. Cheng, D.; He, Q. Assessment of environmental stresses for enhanced microalgal biofuel production-an overview. Front. Energy Res. 2014, 2, 26-30. [CrossRef]

74. Kumaresan, V.; Nizam, F.; Ravichandran, G.; Viswanathan, K.; Palanisamy, R.; Bhatt, P.; Arasu, M.V.; Al-Dhabi, N.A.; Mala, K.; Arockiaraj, J. Transcriptome changes of blue-green algae, Arthrospira sp. in response to sulfate stress. Algal Res. 2017, 23, 96-103. [CrossRef]

75. Hincha, D.K.; Hagemann, M. Stabilization of model membranes during drying by compatible solutes involved in the stress tolerance of plants and microorganisms. Biochem. J. 2004, 383, 277-283. [CrossRef]

76. Carrieri, D.; Ananyev, G.; Lenz, O.; Bryant, D.A.; Dismukes, G.C. Contribution of a sodium ion gradient to energy conservation during fermentation in the cyanobacterium Arthrospira (Spirulina) maxima CS-328. Appl. Environ. Microbiol. 2011, 77, 7185-7194. [CrossRef]

77. Trewavas, A.J.; Rodrigues, C.; Rato, C.; Malhó, R. Cyclic nucleotides: The current dilemma. Curr. Opin. Plant Biol. 2002, 5, 425-429. [CrossRef]

78. Soccol, C.R.; Vandenberghe, L.P.S.; Costa, B.; Woiciechowski, A.L.; de Carvalho, J.C.; Medeiros, A.B.P.; Francisco, A.M.; Bonomi, L.J. Brazilian biofuel program: An overview. J. Sci. Ind. Res. 2005, 64, 897-904.

79. Gulati, M.; Kohlmann, K.; Ladisch, M.R.; Hespell, R.; Bothast, R.J. Assessment of ethanol production options for corn products. Bioresour. Technol. 1996, 58, 253-264. [CrossRef]

80. Mohanty, S.K.; Swain, M.R. Bioethanol production from corn and wheat: Food, fuel, and future. Bioethanol Prod. Food Crops 2019, 45-59. [CrossRef]

81. Bothast, R.J.; Schlicher, M.A. Biotechnological processes for conversion of corn into ethanol. Appl. Microbiol. Biotechnol. 2005, 67, 19-25. [CrossRef]

82. Costa, J.A.V.; Freitas, B.C.B.; Rosa, G.M.; Moraes, L.; Morais, M.G.; Mitchell, B.G. Operational and economic aspects of Spirulinabased biorefinery. Bioresour. Technol. 2019, 292, 121946. [CrossRef] 